\title{
Hydrophilic Gel Amendments to Sand Soil Can Increase Growth and Nitrogen Uptake Efficiency of Citrus Seedlings
}

\author{
J.P. Syvertsen and J.M. Dunlop \\ Citrus Research and Education Center, University of Florida, IFAS, 700 \\ Experiment Station Road, Lake Alfred, FL 33850
}

Additional index words. evapotranspiration, $\mathrm{N}$ leaching, $\mathrm{N}$ budgets

\begin{abstract}
We tested the hypothesis that amendments of two hydrophilic gels to a sand soil would reduce $\mathrm{N}$ leaching losses and increase growth of citrus seedlings. Three-month-old seedlings of 'Swingle' citrumelo [Citrus paradisi Macf. x Poncirus trifoliata (L.) Raf.] were transplanted into containers of steam-sterilized Candler sand, amended with a linear acrylamide/acrylate copolymer (PAM), and/or a cross-linked copolymer agronomic gel (AGRO). Two rates of each amendment were applied either alone or together and were either mixed into dry sand prior to seedling transplant, used as a root-dip slurry at transplant or applied to the soil surface in a solution after transplant. Seedlings were grown in the greenhouse for $\mathbf{5}$ months and irrigated to container capacity with a dilute nutrient solution without leaching. Pots were leached every 2 weeks and total $\mathbf{N}$ losses from the soil were measured in the leachate. PAM amendments increased $\mathrm{N}$ retention in soil slightly but PAM had no effect on plant growth, water use, $\mathrm{N}$ uptake, or $\mathrm{N}$ leaching relative to unamended control plants. The AGRO amendments increased seedling growth, plant water use and uptake of $\mathrm{N}$ from $11 \%$ to $45 \%$ above that of the unamended control plants depending on application method. AGRO decreased $\mathrm{N}$ concentrations in the leachate to as low as 1 to $6 \mathrm{mg} \cdot \mathrm{L}^{-1}$. Only $6 \%$ of the total applied $\mathrm{N}$ was leached from the AGRO treatments, which was about half that from the untreated control plants. There was no additional benefit of using both amendments together or of an additional AGRO root dip treatment. The largest plants used the most water, required the most $\mathrm{N}$ and had the greatest $\mathrm{N}$ uptake efficiency. AGRO amendments clearly enhanced seedling growth, increased their $\mathrm{N}$ uptake efficiency, and reduced $\mathrm{N}$ losses from this sand soil.
\end{abstract}

An important goal of Florida citrus nursery tree production (Maust and Williamson, 1994) and in commercial fruit production in the field (Syvertsen and Smith, 1996) is to maximize fertilizer $\mathrm{N}$ uptake so as to minimize leaching losses. The poor water holding capacity of the sand soils in central Florida and the high summer rainfall that normally exceeds evapotranspiration, combine to make $\mathrm{N}$ leaching losses a serious problem that has been associated with citrus production (Riotte, 1994). Current best management practices recommend multiple split applications of fertilizer to minimize residual soil $\mathrm{N}$ that is susceptible to leaching and avoiding fertilizer applications during the summer rainy season (Tucker et al., 1995). Since intense rain storms are possible at any time of the year, some leaching losses of $\mathrm{N}$ are unavoidable. The percentage of the applied $\mathrm{N}$ that is taken up, the $\mathrm{N}$ uptake efficiency (NUE), is inversely related to the $\mathrm{N}$ status of trees (Smith, 1966). NUE can be increased by reducing $\mathrm{N}$ application rates (Lea-Cox and $\mathrm{Sy}$ vertsen, 1996) or by reducing $\mathrm{N}$ losses through careful fertilizer and irrigation management (Syvertsen and Smith, 1996).

Received for publication 1 Nov. 2002. Accepted for publication 27 May 2003. This research was supported by the Florida Agricultural Experiment Station and approved for publication as Journal Series $\mathrm{R}-08845$. This research was partially supported by a gift from Stockhausen, Inc.
Soil amendments of high organic compost (Turner et al., 1994) or of water absorbing polymers (hydrogel; James and Richards, 1986) can reduce leaching by increasing water holding capacity of sand soils and soilless potting media (Elliot, 1992). The time required for plants to wilt after irrigation can be lengthened by hydrogel amendments to soil (James and Richards, 1986). Although plant growth of roses was enhanced with a hydrogel amendment in pot culture, larger plants suffered more drought stress than the smaller unamended plants in the limited soil volume (Davies et al., 1987). Oak tree transplant survival was decreased by hydrogels (Ingram and Burbage, 1985) so hydrogels apparently can compete with roots for available water.

Growth, nutrient uptake, and protein content of crop plants was increased by incorporating a hydrogel into sand media in pot culture (Magalhaes et al., 1987; Sayed et al., 1991). This implied that plant water relations and nutrient uptake were improved by the hydrogel amendment. Hydrogels can enhance ammonium $\mathrm{N}$ retention in sand (Henderson and Hensley, 1985), but the ability of roots to extract nutrients from hydrogel amended soils is not clear. The purpose of this study was to determine growth and $\mathrm{N}$ uptake of citrus seedlings in hydrogel-amended central Florida sand. We tested the hypothesis that soil amendments of two hydrophilic gels would increase growth and NUE thereby reducing $\mathrm{N}$ leaching losses.
Seedlings of 'Swingle' citrumelo [Citrus paradisi Macf. x Poncirus trifoliata (L.) Raf.] that were 3 months old and $\approx 10 \mathrm{~cm}$ tall were selected for uniformity from the nursery. Roots were gently washed free from the organic soilless potting media and transplanted individually into 0.15 -L containers of steam-sterilized Candler sand (Hyperthemic, uncoated typic Quartzipsamments) on 1 May 2001. Two commercial hydrogel materials were compared. One was a sodium-based linear copolymer of acrylate/polyacrylamide (PAM) and the other a potassium-based cross-linked copolymer agronomic gel (AGRO; Stockhausen, Greensboro, N.C). There were a total of 14 treatments: with and without combinations of soil amendments, with and without seedlings, plus a sand only (no plant, NP) no amendment treatment (Table 1). Different combinations of hydrogels were either uniformly incorporated as dry (DI) material into the sand prior to transplant, used as a root dip slurry during transplant, or applied as a liquid in a single 2-mL surface drench (SD) just after transplant. The hydrogels were applied at concentrations near the commercial recommended rates for transplanting in the nursery (Stockhausen, Technical Bulletin 103-1197). Pots with DI AGRO treatments were under filled with sand to allow for expansion as preliminary tests revealed that AGRO mixed into dry soil at $2.5 \mathrm{mg} \cdot \mathrm{L}^{-1}$ swelled the volume of the hydrated soil $28 \%$. There were six replicate pots in each treatment. Plants were grown for 5 months (until 28 Sept.) in an unshaded greenhouse with maximum photosynthetic active radiation of $1500 \mu \mathrm{mol} \cdot \mathrm{m}^{-2} \cdot \mathrm{s}^{-1}$, natural photoperiod, maximum/minimum temperatures of $38^{\circ} \mathrm{C}$ day $/ 26^{\circ} \mathrm{C}$ night and relative humidities that ranged from $40 \%$ to $100 \%$.

After establishing treatments, all plants were well-irrigated for 2.5 weeks to allow recovery from transplant. On 19 May, all pots were watered to container capacity, allowed to drain and weighed. For $\approx 3$ months thereafter, pots were reweighed every second day and their weight loss was replaced with a diluted commercial liquid fertilizer solution of $7 \mathrm{~N}-2 \mathrm{P}-7 \mathrm{~K}+$ micronutrients, which contained $100 \mathrm{mg} \cdot \mathrm{L}^{-1}$ of total $\mathrm{N}$ (from ammonium nitrate) with an electrical conductivity (EC) of $0.95 \mathrm{~ms} \cdot \mathrm{cm}^{-1}$. Thus, each treatment was fertigated three times per week to container capacity without leaching. On 23 Aug., all pots were irrigated with water (without leaching) alternating with fertigation to avoid any nutrient salt accumulation between leaching events. About every 2 weeks from 21 May until 28 Sept., all pots were leached with water until 10 to $25 \mathrm{~mL}$ of leachate was collected. These samples were frozen until analyzed for concentrations of $\mathrm{NH}_{4}-\mathrm{N}$ and $\mathrm{NO}_{3}-\mathrm{N}$ with a rapid flow analyzer (ALPKEM, 1986; 1989). Concentrations of $\mathrm{NH}_{4}-\mathrm{N}$ and $\mathrm{NO}_{3}-\mathrm{N}$ were combined and expressed as total $\mathrm{N}$ in $\mathrm{mg} \cdot \mathrm{L}^{-1}$. There were a total of nine sets of 84 leachate samples collected during the course of the experiment. To compare sample concentrations at equal volume, $\mathrm{N}$ concentrations were arith- 
Soll Management, Fertilization, \& Irrigation

Table 1. Effects of sodium-based linear copolymer of acrylate/polyacrylamide (PAM) and potassium-based cross-linked copolymer agronomic gel (AGRO) hydrogel soil amendments on total plant dry weight (TPDW), root : shoot dry weight ratio (Rt : Sh) and daytime evapotranspiration (ET) of 8-month-old "Swingle" citrumelo seedlings. Each value is the mean of $n=6$.

\begin{tabular}{|c|c|c|c|c|c|}
\hline Treatment & Symbol & Abbreviated name & TPDW $(g)$ & Rt:Sh & $\mathrm{ET}(\mathrm{mL} / \mathrm{d})$ \\
\hline No plant (NP), no amendment & o & $\mathrm{NP}$ & --- & --- & $6.0 \mathrm{~g}$ \\
\hline$(\mathrm{NP})+$ Surface Drench $(\mathrm{SD}) \mathrm{PAM}$ at $80 \mathrm{mg} \cdot \mathrm{L}^{-1}$ water & 0 & $\mathrm{NP}+\mathrm{SD}$ PAM 80 & --- & --- & $5.8 \mathrm{~g}$ \\
\hline Control Seedlings (no treatment) & - & Control seedlings & $4.06^{y} \mathrm{de}$ & $1.41 \mathrm{a}$ & 20.4 def \\
\hline Dry incorporated (DI) $\mathrm{AGRO}^{2}$ at $2.5 \mathrm{mg} \cdot \mathrm{L}^{-1}$ soil & $\square$ & AGRO & $5.53 \mathrm{ab}$ & $1.12 \mathrm{c}-\mathrm{e}$ & $25.0 \mathrm{~b}$ \\
\hline $\mathrm{SD}$ PAM at $40 \mathrm{mg} \cdot \mathrm{L}^{-1}$ water & $\nabla$ & SD PAM 40 & $4.06 \mathrm{de}$ & $1.36 \mathrm{ab}$ & $19.5 \mathrm{f}$ \\
\hline $\mathrm{SD}$ PAM at $80 \mathrm{mg} \cdot \mathrm{L}^{-1}$ water & $\Delta$ & SD PAM 80 & $3.97 \mathrm{de}$ & $1.30 \mathrm{a}-\mathrm{c}$ & $20.2 \mathrm{ef}$ \\
\hline DI PAM at $27 \mathrm{mg} \cdot \mathrm{L}^{-1}$ soil & $\boldsymbol{\nabla}$ & DI PAM 27 & $4.10 \mathrm{de}$ & $1.24 \mathrm{a}-\mathrm{d}$ & $21.2 \mathrm{de}$ \\
\hline DI PAM at $55 \mathrm{mg} \cdot \mathrm{L}^{-1}$ soil & $\Delta$ & DI PAM 55 & $3.87 \mathrm{e}^{\mathrm{z}}$ & $1.30 \mathrm{a}-\mathrm{c}$ & $21.8 \mathrm{~d}$ \\
\hline $\mathrm{SD}$ PAM at $40 \mathrm{mg} \cdot \mathrm{L}^{-1}$ water + DI AGRO* & $\square$ & SD PAM 40 + AGRO & $4.97 \mathrm{bc}$ & $1.05 \mathrm{e}$ & $25.7 \mathrm{ab}$ \\
\hline SD PAM at $80 \mathrm{mg} \cdot \mathrm{L}^{-1}$ water + DI AGRO & $\diamond$ & SD PAM 80 + AGRO & $4.53 \mathrm{~cd}$ & $1.10 \mathrm{de}$ & $23.7 \mathrm{c}$ \\
\hline DI PAM at $27 \mathrm{mg} \cdot \mathrm{L}^{-1}$ soil + DI AGRO & $\bullet$ & DI PAM 27 + AGRO & $5.55 \mathrm{ab}$ & $1.28 \mathrm{a}-\mathrm{d}$ & $26.6 \mathrm{a}$ \\
\hline DI PAM at $55 \mathrm{mg} \cdot \mathrm{L}^{-1}$ soil + DI AGRO & $\diamond$ & DI PAM 55 + AGRO & $5.76 \mathrm{a}$ & $1.24 \mathrm{a}-\mathrm{d}$ & $25.7 \mathrm{ab}$ \\
\hline $\begin{array}{l}\mathrm{SD} \text { PAM at } 40 \mathrm{mg} \cdot \mathrm{L}^{-1} \text { water }+\mathrm{DI} \text { AGRO + } \\
\left.\text { AGRO root dip (RD at } 3.6 \mathrm{~g} \cdot \mathrm{L}^{-1} \text { water }\right)\end{array}$ & $\bullet$ & $\mathrm{SD}$ PAM $40+\mathrm{AGRO}+\mathrm{RD}$ & $5.47 \mathrm{ab}$ & $1.20 \mathrm{~b}-\mathrm{e}$ & $25.3 \mathrm{ab}$ \\
\hline $\begin{array}{l}\text { DI PAM at } 27 \mathrm{mg} \cdot \mathrm{L}^{-1} \text { soil + DI AGRO + RD } \\
\text { at } 3.6 \mathrm{~g} \cdot \mathrm{L}^{-1} \text { water }\end{array}$ & 0 & DI PAM $27+A G R O+R D$ & $5.81 \mathrm{a}$ & $1.31 \mathrm{a}-\mathrm{c}$ & $26.8 \mathrm{a}$ \\
\hline
\end{tabular}

${ }^{2}$ All DI AGRO treatments were incorporated at $2.5 \mathrm{mg} \cdot \mathrm{L}^{-1} \mathrm{soil}$.

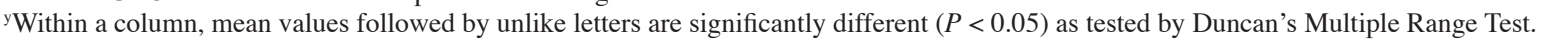

metically standardized to a uniform volume of $25 \mathrm{~mL}$. Unstandardized $\mathrm{N}$ concentrations were multiplied by the volume leached to calculate total $\mathrm{N}$ leached (mg) per sample.

On 25 and 26Sept., plant evapotranspiration (ET) was measured by weight loss from each pot between $0800 \mathrm{HR}$ and $1600 \mathrm{HR}$. Daytime ET (per plant) was calculated as the mean weight loss of $2 \mathrm{~d}$. The sand was gently washed from each root system and plants were separated into roots, stems, and leaves. Total leaf area per plant was measured using a leaf area meter (LI-3000, LI-COR, Lincoln, Nebr.). Plant tissues were dried in an oven at $60^{\circ} \mathrm{C}$ for at least $72 \mathrm{~h}$ and weighed. Since all seedlings were the same size at the beginning of the experiment, we used total plant dry weight (TPDW) to assess plant growth. Root and leaf samples were milled to a powder for Kjeldahl analysis of total $\mathrm{N}$ concentration. Total $\mathrm{N}$ contents $(\mathrm{mg})$ of leaves and roots were calculated by multiplying the $\mathrm{N}$ concentration (percentage dry weight) in leaves and roots by their respective dry weight. The concentration of $\mathrm{N}$ in stems was estimated as 0.5 that in leaves (Syvertsen and Yelenosky, 1988) and used to calculate N content in stems. Leaf, root, and stem $\mathrm{N}$ content were summed to calculate total plant $\mathrm{N}$ content of each plant. This was done both at the end of the study and also at the beginning of the study when initial $\mathrm{N}$ contents of six seedlings at the time of transplant averaged $18 \mathrm{mg}$ of $\mathrm{N}$ per plant. The total plant $\mathrm{N}$ uptake during the experiment was calculated by subtracting 18 $\mathrm{mg} \mathrm{N}$ from each total plant $\mathrm{N}$ content at the end of the study. Nitrogen uptake efficiency (NUE in percent $\mathrm{N}$ applied ) was calculated as $(\mathrm{N}$ uptake/ $\mathrm{N}$ applied $) \times 100$.

The experiment was a completely randomized design with 14 treatments and 6 replicate pots in each treatment. Data were tested for significant differences by analysis of variance and treatment means were separated by Duncan's multiple range test (SAS Institute, Cary, N.C.) at $P<0.05$. Regression analysis was used to test for correlations between selected variables when appropriate.

\section{Results}

Soil amendments with PAM alone had no effect on plant growth regardless of application method or rate (Table 1). Plants in soil amended with AGRO grew more than the untreated control plants. Plant growth in the additional PAM surface drench treatment (SD PAM $40+$ AGRO) did not differ from those in the AGRO alone treatment. The SD PAM 80 + AGRO plants were smaller than those treated with AGRO alone. After AGRO was incorporated into the soil, the additional applications of AGRO as a root dip or of PAM incorporated into the soil had no effect on plant growth. Root and shoot dry weights (data not shown) generally ranked in the same order as TPDW. Overall, there was no correlation $(r=0.005)$ between TPDW and the root:shoot dry weight ratio(Rt:Sh). Control seedlings had the highest Rt:Sh and the SD PAM 40 + AGRO plants had the lowest Rt:Sh.

The soil evaporation components of ET from the two no plant (NP) treatments did not differ and averaged $\approx 21 \%$ to $30 \%$ of the ET of the treatments with seedlings (Table 1). Among the PAM amended treatments, the SD treatments tended to have a lower ET than the DI treatments. The SD PAM at the high $\left(80 \mathrm{mg} \cdot \mathrm{L}^{-1}\right)$ rate $+\mathrm{AGRO}$, decreased the ET below that of AGRO alone but was greater than SD PAM 80 alone. The larger plants with

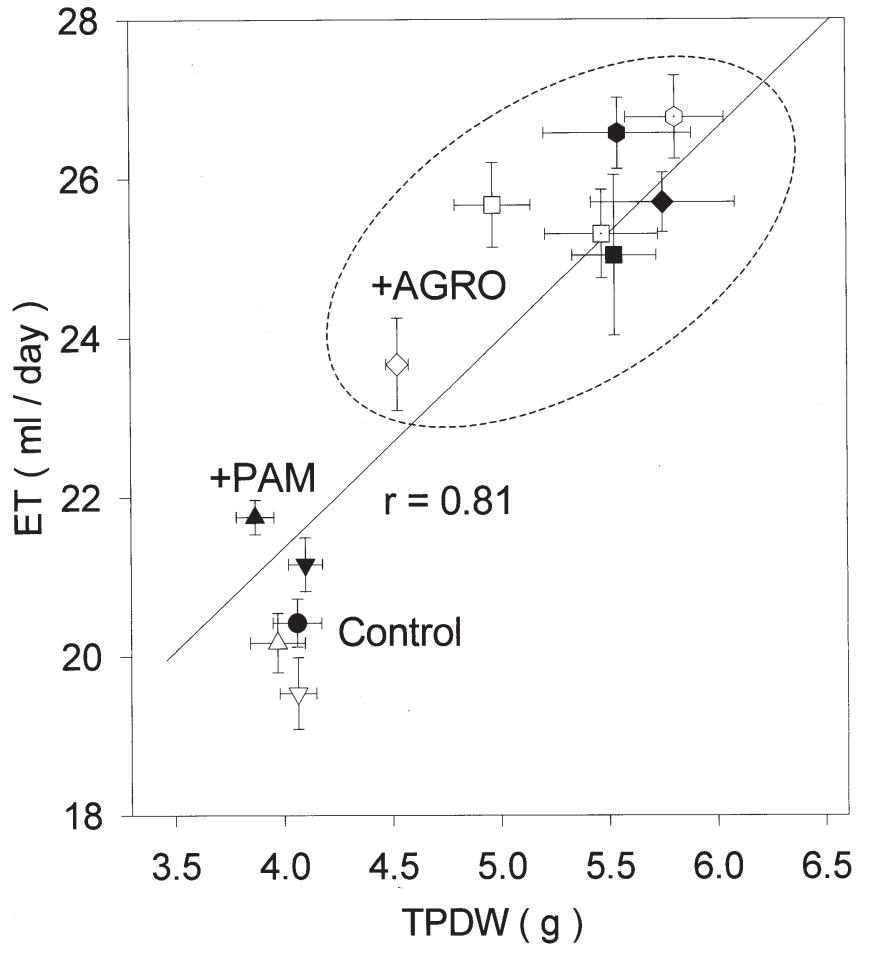

Fig. 1. The relationship between daytime evapotranspiration (ET) and total plant dry weight (TPDW) of 'Swingle' citrumelo seedlings at the end of the experiment. Each point represents the mean ( $\mathrm{n}=6 \pm$ $\mathrm{SE})$ of each treatment; see Table 1 for the key to symbols. 
the AGRO amendments differed little in their water use. The two AGRO + root dip treatments had no effect on ET compared with the ET of their respective AGRO treatments without the additional root dip. There was a positive correlation between TPDW and ET as the larger plants used more water (Fig. 1).

Since fertilizer was added with each irrigation, treatments with larger plants that required more water also received more total $\mathrm{N}$ in the fertigation applications (Fig. 2a). The arrow $(\uparrow)$ indicates when irrigations began alternating with fertigations. The plotted treatments represent the entire range but some of the intermediate treatment plots have been deleted for clarity. The two treatments with no plants (NP) received the least $\mathrm{N}$ applied but leached the highest concentrations of $\mathrm{N}$ (Fig. 2b). By the beginning of July, the $\mathrm{N}$ application rates apparently matched the plant uptake rates as concentrations of total $\mathrm{N}$ in the leachate (standardized to $25 \mathrm{~mL}$ ) generally began decreasing across all treatments. On 13 Sept., $\mathrm{N}$ concentrations in the leachate varied from only 1.1 to $6.8 \mathrm{mg} \cdot \mathrm{L}^{-1}$. Throughout the study, concentrations of leached $\mathrm{NO}_{3}-\mathrm{N}$ exceeded that of $\mathrm{NH}_{4}-\mathrm{N}$ on every sampling day (data not shown). The total accumulated $\mathrm{N}$ that leached from treatments with plants ranged from a low of $\approx 5 \mathrm{mg}$ for the AGRO treatment to $10 \mathrm{mg}$ for the DI PAM 55 treatment.(Fig. 2c). The greatest amount of total $\mathrm{N}$ leached was the 19 to $20 \mathrm{mg}$ from the two NP treatments, which did not differ significantly (Table 2). The addition of PAM as a surface drench $(\mathrm{NP}+\mathrm{SD}$ PAM 80), however, reduced the percentage of

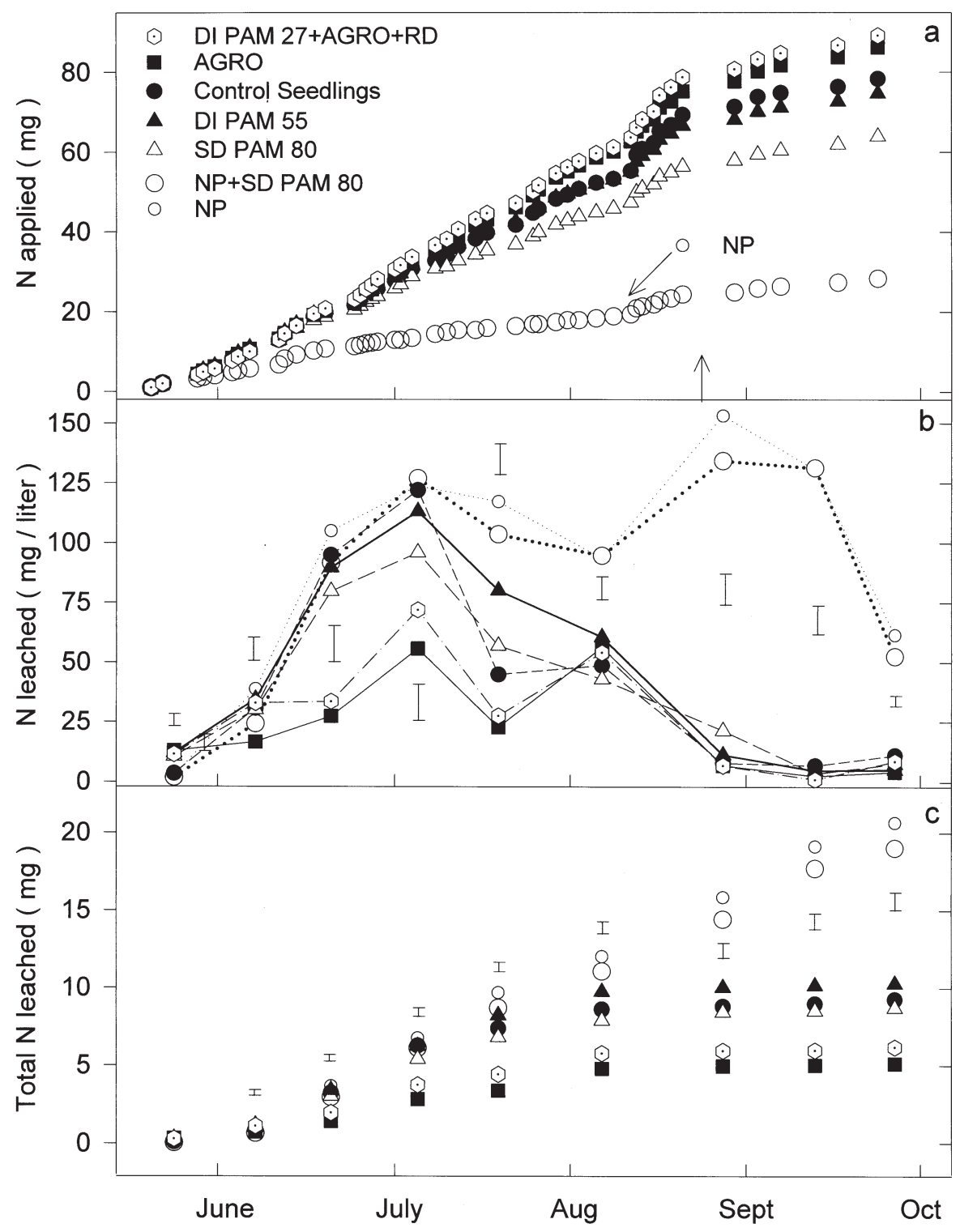

Fig. 2. The average $(n=6)$ accumulated $N$ applied $(\mathbf{a})$, concentration of $N$ in the leachate standardized to a volume of $25 \mathrm{~mL}(\mathbf{b})$, and accumulated total $\mathrm{N}$ leached (c) from six selected treatments during the course of the experiment. The plotted treatments represent the entire range of data but some of the intermediate treatments have been deleted for clarity. The arrow $(\uparrow)$ in (a) indicates when irrigations began alternating with fertigations. In (a), the symbols representing the no plant (NP) + SD PAM 80 treatment ( O ) overlay the NP (o) treatment. There was no variation within N application treatments (a) since all six replicates received the same amount of fertigation. Vertical bars in (b) and (c) are the averaged standard error of plotted treatments.
$\mathrm{N}$ recovered in the leachate to $67 \%$ of the $\mathrm{N}$ applied compared with $73 \%$ leached from the NP untreated control. Although the treatments with seedlings received about two to three times more $\mathrm{N}$ than the NP treatments without plants, treatments with seedlings only leached $\approx 6 \%$ to $13 \%$ of the $\mathrm{N}$ applied. PAM amended plants leached $\approx 13 \%$ of the $\mathrm{N}$ applied which did not differ from that of the untreated control plants. Amendments with AGRO reduced the percentage of $\mathrm{N}$ leached to $\approx 6 \%$ to $9 \%$ of that applied and AGRO alone had the lowest percentage of $\mathrm{N}$ leached. The combined treatment of SD PAM 80 + AGRO increased N leaching losses above that from AGRO alone so the leaching losses from the combined treatment was intermediate between the control plants and other AGRO treatments.

Leaf $\mathrm{N}$ concentrations were generally in the low range and the AGRO alone treatment and the two SD PAM +AGRO treatments were $\mathrm{N}$ deficient, $<2.2 \% \mathrm{~N}$ for bearing trees (Tucker et al., 1995; Table 2). Only the smallest plants (DI PAM 55 treatment) had leaf $\mathrm{N}$ concentration that approached the optimum range of $2.5 \%$ to $2.8 \%$. There was a negative correlation $(r=-0.48 ; P<0.05)$ between leaf $\mathrm{N}$ and TPDW. Root $\mathrm{N}$ concentration (data not shown) was not correlated with leaf $\mathrm{N}$, but larger plants did have higher $\mathrm{N}$ in roots as root $\mathrm{N}$ was correlated $(r=0.32, P<0.05)$ with TPDW. The larger AGRO amended plants took up the most $\mathrm{N}$ over the duration of the experiment. Total $\mathrm{N}$ uptake of the smaller PAM amended plants was less than the AGRO plants and did not differ from the unamended control plants. Plants in the SD PAM 80 treatment took up the least amount of N. Nitrogen uptake efficiency (NUE) varied from $\approx 55 \%$ in the untreated and PAM amended plants up to $81 \%$ in the largest AGRO treated plants. The addition of the SD PAM 80 to the +AGRO, lowered NUE to intermediate between that of AGRO alone and SD PAM 80 alone. The additional AGRO root dip treatment to the SD PAM 40 + AGRO treatment, significantly increased total $\mathrm{N}$ uptake but not sufficiently to increase the NUE of the SD PAM $40+$ AGRO + root dip plants over that of the SD PAM 40 + AGRO plants. The DI PAM 27 + AGRO plus AGRO root dip similarly increased NUE slightly over the DI PAM 27 + AGRO treatment, but not significantly so. Although there was no correlation between NUE and total N applied within the PAM treated plants, NUE was positively correlated with $\mathrm{N}$ applied over all treatments (Fig. 3).

\section{Discussion}

We wanted to determine if soil amendments of these two hydrophilic gels would increase growth and $\mathrm{N}$ uptake efficiency thereby reducing $\mathrm{N}$ leaching losses. Although there was no correlation between plant size and the relative amount of growth allocated to roots or shoots, the soil amendments affected growth allocation patterns as the untreated control plants had the highest Rt:Sh ratio. Since several of the DI AGRO treatments had lower Rt:St ratios than control plants, a relatively smaller root 
Soll Management, Fertilization, \& Irrigation

Table 2. Effects of PAM and AGRO hydrogel soil amendments on components of the N budget and plant $\mathrm{N}$ uptake efficiency (NUE) of 8-month-old 'Swingle' citrumelo seedlings. Each value in the mean of $\mathrm{n}=6$ plants. See Table 1 for treatment descriptions.

\begin{tabular}{lcccccc}
\hline & $\begin{array}{c}\text { Total N } \\
\text { applied }(\mathrm{mg})\end{array}$ & $\begin{array}{c}\text { Total N } \\
\text { leached }(\mathrm{mg})\end{array}$ & $\begin{array}{c}\text { N leached/ } \\
\text { N applied }(\%)\end{array}$ & $\begin{array}{c}\text { Leaf N } \\
(\%)\end{array}$ & $\begin{array}{c}\text { Total N } \\
\text { uptake }(\mathrm{mg})\end{array}$ & $\begin{array}{c}\text { NUE } \\
(\%)\end{array}$ \\
\hline No plant (NP), no amendment & $28.2^{\mathrm{z}}$ & $20.7 \mathrm{a}^{\mathrm{y}}$ & $73.2 \mathrm{a}$ & --- & --- & --- \\
NP + SD PAM 80 & 28.4 & $19.0 \mathrm{a}$ & $67.0 \mathrm{~b}$ & --- & --- & --- \\
Control seedlings & 78.3 & $9.2 \mathrm{~b}-\mathrm{d}$ & $11.8 \mathrm{~cd}$ & $2.45 \mathrm{ab}$ & $43 \mathrm{ef}$ & $55 \mathrm{e}$ \\
AGRO & 86.2 & $5.1 \mathrm{f}$ & $6.0 \mathrm{e}$ & $2.11 \mathrm{e}$ & $60 \mathrm{bc}$ & $70 \mathrm{bc}$ \\
SD PAM 40 & 72.1 & $9.4 \mathrm{bc}$ & $13.0 \mathrm{c}$ & $2.35 \mathrm{bc}$ & $40 \mathrm{ef}$ & $55 \mathrm{e}$ \\
SD PAM 80 & 63.9 & $8.4 \mathrm{~b}-\mathrm{d}$ & $13.1 \mathrm{c}$ & $2.30 \mathrm{bc}$ & $36 \mathrm{f}$ & $57 \mathrm{de}$ \\
DI PAM 27 & 75.8 & $10.1 \mathrm{~b}$ & $13.3 \mathrm{c}$ & $2.37 \mathrm{a}-\mathrm{c}$ & $41 \mathrm{ef}$ & $55 \mathrm{e}$ \\
DI PAM 55 & 74.6 & $10.0 \mathrm{~b}$ & $13.4 \mathrm{c}$ & $2.48 \mathrm{a}$ & $42 \mathrm{ef}$ & $56 \mathrm{e}$ \\
SD PAM 40 + AGRO & 82.0 & $6.2 \mathrm{ef}$ & $7.6 \mathrm{de}$ & $2.14 \mathrm{de}$ & $56 \mathrm{~cd}$ & $68 \mathrm{~b}-\mathrm{d}$ \\
SD PAM 80 + AGRO & 78.2 & $7.6 \mathrm{c}-\mathrm{e}$ & $9.7 \mathrm{cde}$ & $2.08 \mathrm{e}$ & $48 \mathrm{de}$ & $61 \mathrm{c}-\mathrm{e}$ \\
DI PAM 27 + AGRO & 89.2 & $7.1 \mathrm{~d}-\mathrm{f}$ & $8.0 \mathrm{de}$ & $2.28 \mathrm{c}$ & $67 \mathrm{ab}$ & $75 \mathrm{ab}$ \\
DI PAM 55 + AGRO & 94.1 & $7.9 \mathrm{c}-\mathrm{e}$ & $8.4 \mathrm{de}$ & $2.28 \mathrm{c}$ & $69 \mathrm{a}$ & $73 \mathrm{ab}$ \\
SD PAM 40 + AGRO + RD & 94.5 & $7.8 \mathrm{c}-\mathrm{e}$ & $8.2 \mathrm{de}$ & $2.26 \mathrm{~cd}$ & $71 \mathrm{a}$ & $75 \mathrm{ab}$ \\
DI PAM 27 + AGRO + RD & 89.2 & $6.2 \mathrm{ef}$ & $6.9 \mathrm{de}$ & $2.26 \mathrm{~cd}$ & $72 \mathrm{a}$ & $81 \mathrm{a}$ \\
\hline
\end{tabular}

${ }^{\mathrm{z}}$ Variation within $\mathrm{N}$ application treatments could not be tested since all six replicates received the same amount of fertigation.

${ }^{y}$ Within a column, mean values followed by unlike letters are significantly different $(P<0.05)$ as tested by Duncan's Multiple Range Test.

system supported a larger shoot than control plants presumably through improved water use. The SD PAM $40+$ AGRO treatment had the smallest Rt:Sh ratio implying that this combined treatment improved plant water use better than other treatments.

The current recommended use of the single stranded polymer, PAM, is for soil erosion control as a dry application at the soil surface at $10 \mathrm{mg} \cdot \mathrm{L}^{-1}$. We speculated that higher concentrations of PAM either applied as a liquid on the sand surface at 40 or $80 \mathrm{mg} \cdot \mathrm{L}^{-1}$ or dry-incorporated into sand at 27 or $55 \mathrm{mg} \cdot \mathrm{L}^{-1}$, would not only hold sand particles in place, but also reduce leaching. However, there was no difference in $\mathrm{N}$ losses between any of the PAM treatments and the untreated control seedlings. Although the surface treated PAM

treatment with no plant did reduce $\mathrm{N}$ leaching to less than that from the untreated sand with no plant, this small reduction attributable to PAM was not reflected in any reduced $\mathrm{N}$ losses from the treatments with plants. Plants in the two PAM-incorporated treatments tended to use more water than the surface applied PAM treatments but there was no significant effect of PAM treatments on ET or plant growth relative to the untreated control seedlings.

In the pots with no plant, the surface application of PAM (SD PAM 80) did not reduce the evaporation component of ET even though this PAM treatment did reduce the percentage of $\mathrm{N}$ leached below that from the untreated sand. This is direct evidence that $\mathrm{N}$ retention was increased significantly by PAM alone. When combined with AGRO, the same SD PAM 80

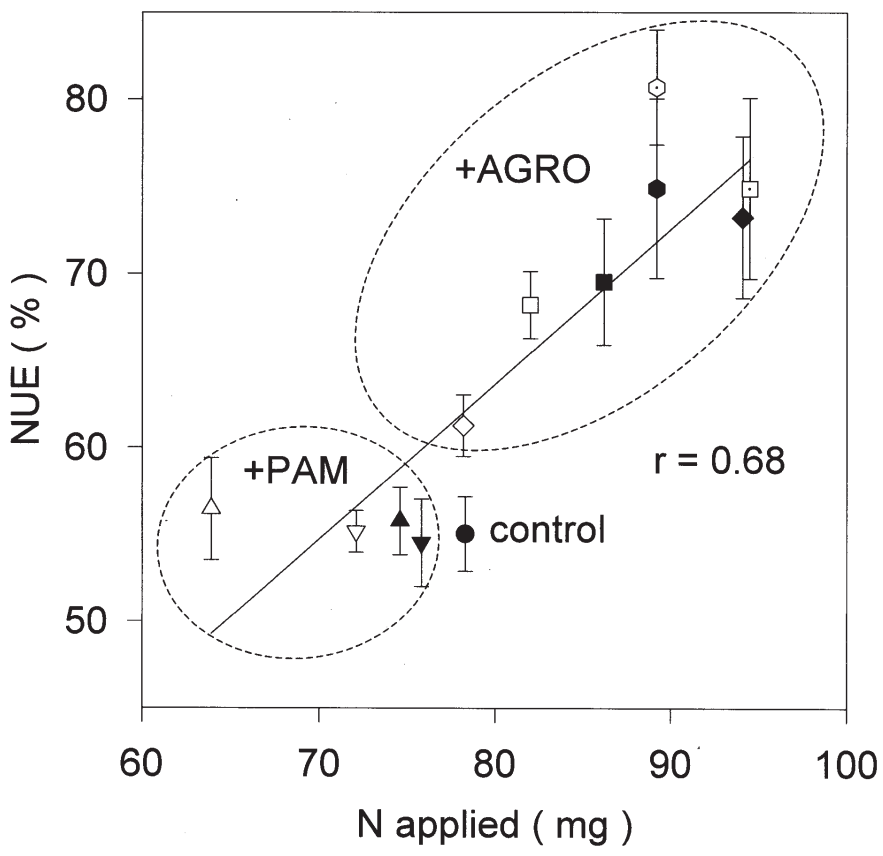

Fig. 3. The relationship between nitrogen uptake efficiency (NUE) and total $\mathrm{N}$ applied to 'Swingle' citrumelo seedlings. Each point represents the mean $(n=6 \pm S E)$ of each treatment; see Table 1 for the key to symbols. treatment not only reduced ET and plant growth below the other AGRO treatments (Fig. 1), but this treatment also decreased NUE below the AGRO treatments. Under the conditions of this study, the combined PAM + AGRO soil amendments apparently competed with seedlings for both water and $\mathrm{N}$.

Plants in the treatments with the crosslinked polymer gel, AGRO, grew more and allowed less $\mathrm{N}$ to leach than untreated control plants even though the larger AGRO treated plants received a much higher application of $\mathrm{N}$. There was not a significant benefit using an additional AGRO root drip treatment over that of the DI AGRO alone. Based on the increased $\mathrm{N}$ concentration in roots of the larger plants, the DI AGRO amendments probably retained more $\mathrm{N}$ in the soil, especially $\mathrm{NH}_{4}-\mathrm{N}$ (data not shown; Henderson and Hensley, 1985), than untreated sand, but there was no AGRO alone treatment with no plant for direct comparisons. Higher application rates of $\mathrm{N}$ and root $\mathrm{N}$ concentrations did not translate to higher concentrations of leaf $\mathrm{N}$ as only the smallest plants had leaf $\mathrm{N}$ concentrations considered sufficient for bearing trees (Tucker et al., 1995). Using the highest average daytime ET of $27 \mathrm{~mL} /$ day (Fig. 1) and the $\mathrm{N}$ concentration in the fertigation water of $100 \mathrm{mg} \cdot \mathrm{L}^{-1}$, the largest plants received an average of $2.7 \mathrm{mg}$ of $\mathrm{N}$ per day or $\approx 19 \mathrm{mg} \mathrm{N}$ per week. This is a relatively low rate to maintain high leaf $\mathrm{N}$ concentrations in potted citrus seedlings, but thought to be a good rate to minimize $\mathrm{N}$ leaching (Lea-Cox and Syvertsen, 1996). This rate was chosen to avoid any fertilizer salt accumulation during the 2 -week periods with no leaching. Considering the low $\mathrm{N}$ application rates and small leaching losses along with the negative correlation between leaf $\mathrm{N}$ and plant size, there must have been a growth dilution effect on leaf $\mathrm{N}$ in the larger plants. Although there was no evidence of $\mathrm{N}$ supply limiting plant growth, it is possible that higher $\mathrm{N}$ rates could have promoted more growth.

Plants received the same rate of potassium (K) as $\mathrm{N}$ but we did not measure concentrations of leaf $\mathrm{K}$. It is unlikely that the K-based cross-linked AGRO material added any significant $\mathrm{K}$ to the soil as this polymer material breaks down very slowly in the field over a period of 2 to 4 years (J. McLeod, personal communication).

The AGRO plants had a much higher NUE than untreated and PAM treated plants. It is important to note that seedling growth and water requirements dictated the rate of $\mathrm{N}$ fertilizer that was applied with the irrigation water. Thus, the fastest growing treatments that used the most water, also received the highest $\mathrm{N}$ rates. We have measured NUE as high as $60 \%$ for potted citrus seedlings (LeaCox and Syvertsen, 1996) and as high as 68\% of that applied to lysimeter-grown bearing trees (Syvertsen and Smith, 1996). In both cases, NUE declined with increasing rates of $\mathrm{N}$ application. The percentage of the annual amount of $\mathrm{N}$ applied that is removed with the crop can be as high as $80 \%$ in $\mathrm{N}$-deficient trees but decreases to $<34 \%$ in the larger crops of trees fertilized with higher rates of N (Smith, 
1966). The AGRO soil amendments in this pot study, had NUE that varied from $61 \%$ to $75 \%$ and up to $81 \%$ when both AGRO and PAM were incorporated into the soil prior to transplant and combined with a AGRO root dip at the time of transplant. The NUE results of this study are not only very high, but also are unusual in that NUE increased with the increasing rate of $\mathrm{N}$ applied. This result was probably not only due to increasing $\mathrm{N}$ retention in this soil in pots, but also due to the relatively low application rates of $\mathrm{N}$ and careful watering that avoided leaching.

The AGRO treatments clearly increased growth, water use and $\mathrm{N}$ uptake of 'Swingle' seedlings while reducing $\mathrm{N}$ leaching losses. Low $\mathrm{N}$ rates, enhanced growth and high $\mathrm{N}$ uptake undoubtedly reduced residual soil $\mathrm{N}$ that was susceptible to leaching. Amendments also increased water and $\mathrm{N}$ retention, thereby enhancing total $\mathrm{N}$ uptake efficiency. Although these results cannot be extrapolated to the field, such soil amendments to improve plant growth and $\mathrm{N}$ uptake could have immediate application in nursery production and could be of potential benefit in managing citrus resets in sand soil.

\section{Literature Cited}

ALPKEM Corporation. 1986. Rapid flow analyzer methodology for nitrate and nitrite nitrogen. A303-S170. ALPKEM Corp., Clackamas, Ore

ALPKEM Corporation. 1989. Rapid flow analyzer methodology for ammonia nitrogen. A303-S020. ALPKEM Corp., Clackamas, Ore.

Davies, F.T., Jr., Y. Castro-Jimenez, and S.A. Duray. 1987. Mycorrhizae, soil amendments, water relations and growth of Rosa multiflora under reduced irrigation regimes. Scientia Hort. 33:261-267.

Elliott, G.C. 1992. Imbibition of water by rockwoolpeat container media amended with hydrophilic gel or wetting agent. J. Amer. Soc. Hort. Sci. 117:757-761.

Henderson, J.C. and D.L. Hensley. 1985. Ammonium and nitrate retention by a hydrophilic gel. HortScience 20:667-668.

Ingram, D.L. and W. Burbage. 1985. Effects of irrigation regime, antitranspirants, and a water absorbing polymer on the survival and establishment of transplanted live oaks. Proc. Fla. State Hort. Soc. 98:85-87.

James, E.A. and D. Richards. 1986. The influence of iron source on the water-holding properties of potting media amended with water-absorbing polymers. Scientia Hort. 28:201-208

Lea-Cox, J.D. and J.P. Syvertsen. 1996. How nitrogen supply affects growth and nitrogen uptake, use efficiency and loss from citrus seedlings. J. Amer. Hort. Sci. 121:105-114.

Maust, B.E. and J.G. Williamson. 1994. Nitrogen nutrition in containerized citrus nursery plants. J. Amer. Hort. Sci. 119:195-201.
Magalhaes, J.R., G.E. Wilcox, F.C. Rodrigues, F.L.I.M. Silva, and A.N. Ferreira Rocha. 1987. Plant growth and nutrient uptake in hydrophilic gel treated soil. Commun. Soil Sci. Plant Anal. 18:1469-1478.

Riotte, W. 1994. Ridge citrus water quality project annual (1993) report. Fla. Dept. Agr. Cons. Serv., Tallahassee. $33 \mathrm{p}$.

Sayed, H.E., R.C Kirkwood, and N.B. Graham. 1991. The effects of a hydrogel polymer on the growth of certain horticultural crops under saline conditions. J. Expt. Bot. 42:891-899.

Smith, P.F. 1966. Citrus nutrition, p. 174-207. In N.F. Childers (ed.). Nutrition of fruit crops. Tropical, sub-tropical, temperate, and small fruits. Somerset Press, Sommerville, N.J.

Syvertsen, J.P. and M.L. Smith. 1996. Nitrogen uptake efficiency and leaching losses from lysimeter-grown Citrus trees fertilized at three nitrogen rates. J. Amer. Soc. Hort. Sci. 121:57-62.

Syvertsen, J.P. and G. Yelenosky. 1988. Salinity can enhance freeze tolerance of citrus rootstock seedlings by modifying growth, water relations, and mineral nutrition. J. Amer. Soc. Hort. Sci. 13:889-893.

Tucker, D.P.H., A.K. Alva, L.K. Jackson, and T.A Wheaton (eds.). 1995. Nutrition of Florida citrus trees. SP-169. Univ. Fla., Gainesville. 61 p.

Turner, M.S., G.A. Clark, C.D. Stanley, and A.G. Smajstrla. 1994. Physical characteristics of a sandy soil amended with municipal solid waste compost. Soil Crop Sci. Soc. Fla. Proc. 53:24-26. 